\title{
Star-shaped Triphenylamine-thienylenevinylenes Hybrid Systems with Internal Charge- transfer as Donor Materials for Heterojunction Solar Cells
}

Sophie Roquet, Antonio Cravino, Philippe Leriche, Olivier Alevêque, Pierre Frère, Jean Roncali

\section{Experimental}

\section{Synthesis}

Tris[4-(2-thienyl)phenyl]amine (9). To a solution of tris(4-bromophenyl)amine 12 (Aldrich) (1g, 2mmol) in $100 \mathrm{~mL}$ of toluene, are added 2-tributylstannylthiophene (2.9 mL, $4.5 \mathrm{eq}$ ) and $\mathrm{Pd}\left(\mathrm{PPh}_{3}\right)_{4} \quad 27 \mathrm{mg}(1.1 \mathrm{~mol} \%)$. The mixture is refluxed $12 \mathrm{~h}$ under inert atmosphere and cooled to room temp. The solution is washed with brine and dried over $\mathrm{MgSO}_{4}$. After solvent evaporation the residue is rinsed with petroleum ether and filtrated to give $0.868 \mathrm{~g}$ (85\%) of a yellow solid M.p. $139^{\circ} \mathrm{C} .{ }^{1} \mathrm{H}$ NMR $\left(\mathrm{CDCl}_{3}\right) 7.50$ (d, 2H, $\left.{ }^{3} \mathrm{~J}=8.00 \mathrm{~Hz}\right), 7.20$ (m, 2H), 7.10 (d, $2 \mathrm{H},{ }^{3} \mathrm{~J}=8.00 \mathrm{~Hz}$ ), 7.08 (dd, $1 \mathrm{H},{ }^{3} \mathrm{~J}=3.75 \mathrm{~Hz},{ }^{4} \mathrm{~J}=5.00 \mathrm{~Hz}$ ). MS MALDI-TOF calcd for $\mathrm{C}_{30} \mathrm{H}_{21} \mathrm{NS}_{3}$ 491, found 491 (M.+)

Tris[4-(5-formyl-2-thienyl)phenyl]amine (8). Tris[4-(2-thienyl)phenyl]amine (9) (500 mg, $1 \mathrm{mmol}$ ) is dissolved in 30mL of 1,2-dichloroethane. DMF (371 mg, 5eq) and $\mathrm{POCl}_{3}$ (781 mg, 5eq) are added dropwise and the mixture is refluxed $15 \mathrm{~h}$ under nitrogen. After cooling to room temp and addition of $50 \mathrm{~mL}$ of dichloromethane and $100 \mathrm{~mL}$ of a saturated aqueous solution of sodium acetate, the mixture is stirred $2 \mathrm{~h}$ at room temp. The organic phase is then washed with water and dried over $\mathrm{MgSO}_{4}$. Solvent removal and column chromatography (silica gel/dichloromethane) gave $0.53 \mathrm{~g}(90 \%)$ of an orange solid. M.p. $230^{\circ} \mathrm{C} .{ }^{1} \mathrm{H}$ NMR $\left(\mathrm{CDCl}_{3}\right) 9.90$ (s, $\left.1 \mathrm{H}\right), 7.70$ (d, $\left.1 \mathrm{H},{ }^{3} \mathrm{~J}=3.75 \mathrm{~Hz}\right), 7.60$ (d, $\left.1 \mathrm{H},{ }^{3} \mathrm{~J}=3.75 \mathrm{~Hz}\right), 7.30$ (d, $2 \mathrm{H}$, ${ }^{3} \mathrm{~J}=8.00 \mathrm{~Hz}$ ), 7.20 (d, $\left.2 \mathrm{H},{ }^{3} \mathrm{~J}=8.00 \mathrm{~Hz}\right) .1^{3} \mathrm{C} \mathrm{NMR}\left(\mathrm{CDCl}_{3}\right)$ 182.7, 153.6, 147.5, 142.0, 137.6, 128.4, 127.6, 124.6, 123.6. IR ( $\mathrm{KBr} n \quad\left(\mathrm{~cm}^{-1}\right) 1659(\mathrm{C}=\mathrm{O})$. MS MALDI-TOF calcd for $\mathrm{C}_{33} \mathrm{H}_{21} \mathrm{NO}_{3} \mathrm{~S}_{3} 575$, found $575(\mathrm{M}+$.)

\section{Tris\{4-[5-(2-thienylethen-2-yl)-2-thienyl]phenyl\}amine (1).}

Tris[4-(5-formyl-2-thienyl)phenyl]amine 8 (0.3g, 0.5 mmol), and 2-(diethoxyphosphorylmethyl)thiophene ( $0.55 \mathrm{~g}$, 5 . eq) are dissolved in $50 \mathrm{~mL}$ of dry THF under nitrogen atmospher. t-BuOK (0.29 g, 5 eq) are added potion wise during 30' after what the solution is stirred $1 \mathrm{~h}$. 
Addition of methanol leads to the precipitation of $300 \mathrm{mg}$ (70\%) of orange solid ,M.p. $130^{\circ} \mathrm{C}$. ${ }^{1} \mathrm{H}$ NMR $\left(\mathrm{C}_{6} \mathrm{D}_{6}\right) 7.50$ (d, 2H, ${ }^{3} \mathrm{~J}=8.00 \mathrm{~Hz}$ ), 7.10 (d, $1 \mathrm{H},{ }^{3} \mathrm{~J}=15.50 \mathrm{~Hz}$ ), 7.00 (d, 2H, ${ }^{3} \mathrm{~J}=8.00 \mathrm{~Hz}$ ), 6.95 (d, $1 \mathrm{H},{ }^{3} \mathrm{~J}=15.50 \mathrm{~Hz}$ ), 6.90 (d, $1 \mathrm{H},{ }^{3} \mathrm{~J}=3.75 \mathrm{~Hz}$ ), 6.73 (d, $1 \mathrm{H},{ }^{3} \mathrm{~J}=3.00 \mathrm{~Hz}$ ), 6.70 (d, $1 \mathrm{H}$, $\left.{ }^{3} J=5.00 \mathrm{~Hz}\right), 6.65$ (m, 2H). ${ }^{13} \mathrm{C} \mathrm{NMR}\left(\mathrm{CDCl}_{3}\right): 146.4,142.6,142.5,141.2,129.1,127.7,127.5$, 126.5, 126.0, 124.4, 124.3, 123.0, 121.5, 121.1. UV-vis $\lambda_{\max } n m(\log \varepsilon) 424$ (5.13). HRMS (Fab+, R=7000) calcd for $\mathrm{C}_{48} \mathrm{H}_{33} \mathrm{NS}_{6} 815.0937$ found $815.0973(\mathrm{M}+$.)

\section{Bis\{4-[5-(2-thienylethen-2-yl)-2-thienyl]phenyl\}-[4-(5-formyl-2-thienyl)phenyl]amine}

(6).

Prepared according to the same procedure from tris[4-(5-formyl-2-thienyl)phenyl]amine (0.4 g, $0.7 \mathrm{mmol})$, 2-(diethoxyphosphorylmethyl)thiophene (0.4 g, $2.5 \mathrm{eq})$ and $t$-BuOK (0.19 g, 2.5 eq). After addition of $150 \mathrm{~mL}$ of dichloromethane, the organic phase is washed with water and dried over $\mathrm{MgSO}_{4}$. Solvent removal and column chromatography (silica gel/dichloromethane:petroleum ether 1:1) gave $0.28 \mathrm{~g}$ of 1 (50\%) and $0.1 \mathrm{~g}$ (20\%) of the targeted compound 6 as a red glassy solid. ${ }^{1} \mathrm{H}$ NMR $\left(\mathrm{CDCl}_{3}\right) \delta 9.87(\mathrm{~s}, 1 \mathrm{H}), 7.73(\mathrm{~d}, 1 \mathrm{H}$, ${ }^{3} J=3.96 \mathrm{~Hz}$ ), 7.57 (d, 2H, $\left.{ }^{3} J=8.71 \mathrm{~Hz}\right), 7.53$ (d, 4H, $\left.{ }^{3} J=8.62 \mathrm{~Hz}\right), 7.34$ (d, 1H, ${ }^{3} J=3.95 \mathrm{~Hz}$ ), 7.19 (d, 2H, $\left.{ }^{3} \mathrm{~J}=4.96 \mathrm{~Hz}\right), 7.15$ (m, 8H), 7.01 (m, 10H). ${ }^{13} \mathrm{C} \mathrm{NMR}\left(\mathrm{CDCl}_{3}\right)$ 183.6, 154.2, 148.2, 146.0, 142.4, 142.4, 141.6, 141.4, 137.7, 129.7, 127.7, 127.4, 127.4, 127.1, 126.6, 126.0, 125.0, 124.4, 123.4, 123.2, 123.2, 121.5, 121.3. IR (KBr) v( $\left.\mathrm{cm}^{-1}\right) 1660(\mathrm{C}=\mathrm{O})$. MS MALDITOF calcd for $\mathrm{C}_{43} \mathrm{H}_{29} \mathrm{NOS}_{5} 735$, found $735(\mathrm{M}+$.).

Bis[4-(5-formyl-2-thienyl)phenyl]-\{4-[5-(2-thienylethen-2-yl)-2-thienyl]phenyl\}amine (7). Prepared according to the same procedure from tris[4-(5-formyl-2-thienyl)phenyl]amine (0.5 g, $0.87 \mathrm{mmol}), 2$ (diethoxyphosphorylmethyl)thiophene (0.4 g, 2. eq) and t-BuOK (0.19 g, 2 eq). After addition of $150 \mathrm{~mL}$ of dichloromethane, the organic phase is washed with water and dried over $\mathrm{MgSO}_{4}$. Solvent removal and column chromatography (silica gel/dichloromethane) gave gave the $90 \mathrm{mg}$ (13\%) of compound 1, $120 \mathrm{mg}$ (19\%) of compound 6 and $210 \mathrm{mg}$ (37\%) of the target compound 7 as a red glassy solid. ${ }^{1} \mathrm{H}$ NMR $\left(\mathrm{CDCl}_{3}\right) 9.87(\mathrm{~s}, 2 \mathrm{H}), 7.73(\mathrm{~d}, 2 \mathrm{H}$, $\left.{ }^{3} \mathrm{~J}=3.96 \mathrm{~Hz}\right) 7.59$ (d, 4H, ${ }^{3} \mathrm{~J}=9.41 \mathrm{~Hz}$ ), 7.54 (d, 2H, ${ }^{3} \mathrm{~J}=8.58 \mathrm{~Hz}$ ), 7.34 (d, 2H, ${ }^{3} \mathrm{~J}=3.94 \mathrm{~Hz}$ ), 7.17 (m, 8H), 7.02 (m, 5H. ${ }^{13} \mathrm{C}$ NMR $\left(\mathrm{CDCl}_{3}\right)$ 182.6, 153.9, 147.9, 145.7, 142.4, 142.2, 141.8, 141.7, 137.6, 130.3, 127.8, 127.7, 127.5, 127.4, 126.8, 126.1, 125.4, 124.4, 124.1, 123.4, 121.4. IR (KBr) $\vee\left(\mathrm{cm}^{-1}\right) 1660(\mathrm{C}=\mathrm{O})$. MS MALDI-TOF calcd for $\mathrm{C}_{38} \mathrm{H}_{25} \mathrm{NO}_{2} \mathrm{~S}_{4}$ 655, found $655(\mathrm{M}+$.$) .$

\section{Bis\{4-[5-(2-thienylethenyl)-2-thienyl]phenyl\}\{4-[5-(1,3-dioxoinda-2-ylidenemethyl)-2-}

thienyl]phenyl\} amine (2). To a solution of bis \{4-[5-(2-thienylethenyl)-2-thienyl]phenyl\}-[4(5-formyl-2-thienyl)phenyl]amine $(0.10 \mathrm{~g}, 0.1 \mathrm{mmol})$ in $30 \mathrm{~mL}$ of chloroform are added 
indanedione (30 mg, $1.5 \mathrm{eq}$ ) and $2 \mathrm{~mL}$ of triethylamine and the mixture is refluxed for $12 \mathrm{~h}$ under nitrogen. After cooling to room temperature the solution is washed with water and dried over $\mathrm{MgSO}_{4}$. Solvent removal and column chromatography (silica gel, 1:1 $\mathrm{PE} /$ dichloromethane gave 50mg (43\%) of a red solid. M.p. $222^{\circ} \mathrm{C} .{ }^{1} \mathrm{H}$ NMR $\left(\mathrm{CDCl}_{3}\right): 8.00$ (m, 4H), 7.80 (m, 2H), 7.70 (d, 2H, ${ }^{3} \mathrm{~J}=8.00 \mathrm{~Hz}$ ), 7.55 (d, 4H, ${ }^{3} \mathrm{~J}=8.00 \mathrm{~Hz}$ ), 7.40 (d, $1 \mathrm{H},{ }^{3} \mathrm{~J}=3.75$ $\mathrm{Hz}), 7.20$ (m, 10H), 7.00 (m, 10H). ${ }^{13} \mathrm{CNMR}\left(\mathrm{CDCl}_{3}\right)$ 190.5, 189.8, 157.4, 148.4, 145.9, 143.9, 142.4, 142.4, 142, 141.5, 140.5, 136.2, 136, 134.9, 134.7, 129.8, 127.7, 127.6, 127.5, 127.4, 126.7, 126.1, 125.1, 124.4, 124, 123.4, 123.3, 123.2, 122.9, 122.8, 121.5, 121.3. (KBr) $v\left(\mathrm{~cm}^{-1}\right): 1674(\mathrm{C}=\mathrm{O})$; UV-vis $\lambda_{\max } \mathrm{nm}(\log \varepsilon) 419$ (4.79), 509. HRMS (Fab+, R=7000) calcd for $\mathrm{C}_{52} \mathrm{H}_{33} \mathrm{NO}_{2} \mathrm{~S}_{5} 863.1141$ found $863.1115\left(\mathrm{M}^{+}\right)$

\section{Bis[4-(5-dicyanomethylidenemethyl-2-thienyl)phenyl]-\{4-[5-(2-thienylethenyl)-2-}

thienyl]phenyl\}amine (4). To a solution of Bis[4-(5-formyl-2-thienyl)phenyl]-\{4-[5-(2thienylethenyl)-2-thienyl]phenyl $\}$ amine $(0.2 \mathrm{~g}, 0.3 \mathrm{mmol})$ in $15 \mathrm{~mL}$ of chloroform are added malonodinitrile (0.4 g, $2.05 \mathrm{eq})$ and two drops of triethylamine and the mixture is refluxed 15 $\mathrm{h}$ under nitrogen. After return to room temperature dichloromethane is added, the solution is washed with water and dried over $\mathrm{MgSO}_{4}$. After solvent removal, the residue is chromatographed (silica gel/dichloromethane) to give $0.11 \mathrm{~g}(48 \%)$ of a red solid. M.p. $383^{\circ} \mathrm{C}$ (dec). ${ }^{1} \mathrm{H}$ NMR $\left(\mathrm{CDCl}_{3}\right) \delta 7.76$ (s, 2H), 7.69 (d, 2H, $\left.{ }^{3} \mathrm{~J}=4.12 \mathrm{~Hz}\right), 7.60$ (d, 4H, $\left.{ }^{3} \mathrm{~J}=8.69 \mathrm{~Hz}\right)$, 7.56 (d, 2H, $\left.{ }^{3} \mathrm{~J}=8.58 \mathrm{~Hz}\right), 7.38$ (d, 2H, $\left.{ }^{3} \mathrm{~J}=4.11 \mathrm{~Hz}\right), 7.17$ (m, 8H) 7.02 (m, 5H). ${ }^{13} \mathrm{C}$ NMR $\left(\mathrm{CDCl}_{3}\right): 156.0,150.3,148.3,145.1,142.3,141.8,140.3,133.6,130.9,127.8,127.7,127.4$, 126.9, 126.8, 126.1, 125.9, 124.5, 123.9, 123.9, 123.6, 121.5, 121.3, 114.3, 113.5, 75.8. IR $(\mathrm{KBr}) \vee \quad\left(\mathrm{cm}^{-1}\right): 2220(\mathrm{C} \equiv \mathrm{N}) . \mathrm{UV}-\mathrm{Vis} . \quad \lambda_{\max } \mathrm{nm}(\mathrm{log} \varepsilon)$ 390, 513 (4.97). HRMS (Fab+, $\mathrm{R}=7000$ ) cald for $\mathrm{C}_{44} \mathrm{H}_{25} \mathrm{~N}_{5} \mathrm{~S}_{4} 751.1008$, found $751.0993(\mathrm{M}+$.)

\section{Bis\{4-[5-(2-thienylethenyl)-2-thienyl]phenyl\}-[4-(5-dicyanomethylidenemethyl-2-}

thienyl)phenyl]amine (3). Prepared using the procedure already described for $\mathbf{4}$ from bis $\{4-$ [5-(2-thienylethenyl)-2-thienyl]phenyl\}-[4-(5-formyl-2-thienyl)phenyl]amine (100mg, 0. $14 \mathrm{mmol})$ in $15 \mathrm{~mL}$ of chloroform, malononitrile (19 $\mathrm{mg}, 2.1 \mathrm{eq})$ and two drops of triethylamine. Usual work-up and column chromatography of (silica gel, dichloromethane:petroleum ether 1:1) gives $20 \mathrm{mg}$ (19\%) of a red solid. M.p. $386^{\circ} \mathrm{C}(\mathrm{dec}) .{ }^{1} \mathrm{H}$ NMR (CDCl3) 7.74 (s, 1H), 7.68 (d, 1H, $\left.{ }^{3} J=4.15 \mathrm{~Hz}\right), 7.57$ (d, 2H, ${ }^{3} \mathrm{~J}=8.74 \mathrm{~Hz}$ ), 7.54 (d, 4H, $\left.{ }^{3} J=8.61 \mathrm{~Hz}\right), 7.35(\mathrm{~d}, 1 \mathrm{H}, 3 \mathrm{~J}=4.13 \mathrm{~Hz}), 7.16(\mathrm{~m}, 10 \mathrm{H}), 7.02(\mathrm{~m}, 10 \mathrm{H}),{ }^{13} \mathrm{C} \mathrm{NMR}\left(\mathrm{CDCl}_{3}\right)$ 156.6, 150.3, 149.0, 145.6, 142.4, 142.2, 141.6, 140.3, 133.3, 130.1, 127.7, 127.4, 126.7, 126.1, 125.8, 125.3, 124.4, 123.6, 123.3, 122.8, 121.4, 121.3, 114.5, 113.6, 75.4. IR (KBr v 
$\left(\mathrm{cm}^{-1}\right) 2220(\mathrm{CN}), \mathrm{UV}-\mathrm{Vis} . \quad \lambda_{\max } \mathrm{nm}(\log \varepsilon) 415$ (4.79). HRMS (Fab+, R=7000) calcd for $\mathrm{C}_{46} \mathrm{H}_{29} \mathrm{~N}_{3} \mathrm{~S}_{5}$ 783.0965, found $783.0939\left(\mathrm{M}^{+}\right)$.

Tris(4-(5-dicyanomethylidenemethyl-2-thienyl)phenyl]amine (5). Prepared using the procedure already described for 4 from $200 \mathrm{mg}$ of compound 8 in $15 \mathrm{~mL}$ of chloroform. Malononitrile (70mg, 3.06eq) and two drops of triethylamine. Usual work-up and column chromatography eluting with dichloromethane then with 20:1 dichloromethane/ethyl acetate gave $0.19 \mathrm{~g}$ (76\%) of a red solid. M.p. $325^{\circ} \mathrm{C}(\mathrm{dec}) .{ }^{1} \mathrm{H}$ NMR $\left(\mathrm{CDCl}_{3}\right): 7.79$ (s, $\left.1 \mathrm{H}\right), 7.71$ (d, $1 \mathrm{H},{ }^{3} \mathrm{~J}=4.13 \mathrm{~Hz}$ ), 7.64 (d, $2 \mathrm{H},{ }^{3} \mathrm{~J}=8.69 \mathrm{~Hz}$ ), 7.41 (d, $1 \mathrm{H},{ }^{3} \mathrm{~J}=4.09 \mathrm{~Hz}$ ), 7.20 (d, 2H, ${ }^{3} \mathrm{~J}=8.69 \mathrm{~Hz}$ ). ${ }^{13} \mathrm{C}$ NMR $\left(\mathrm{CDCl}_{3}\right)(155.6,150.4,147.8,140.2,133.9,128.0,127.8,124.8,124.1,114.2$, 113.4, 76.3. IR (KBr) $v\left(\mathrm{~cm}^{-1}\right) 2220(\mathrm{C} \equiv \mathrm{N})$, UV-vis $\lambda_{\max } \mathrm{nm}(\log \varepsilon) 368,509$ (5.09). HRMS (Fab+, $\mathrm{R}=7000$ ) calcd for $\mathrm{C}_{42} \mathrm{H}_{21} \mathrm{~N}_{7} \mathrm{~S}_{3} 719.1021$, found $719.1020\left(\mathrm{M}^{+}\right)$.

PCBM was synthesized according to a known procedure. ${ }^{29}$ Fullerene $\mathrm{C}_{60}(99+\%)$ was purchased from Merck and used without further purification. Indium-tin-oxide (ITO) coated glass substrates (Solems) with a sheet resistance of $40 \mathrm{ohm} / \mathrm{square}$ were cleaned in ultrasonic bath with aqueous detergent, acetone and ethanol dried in an oven and treated 15 min with an UV-ozone cleaner (Jelight 42-220, 28W/ $\mathrm{cm}^{2}$ ). ITO substrates were then spin-coated with a 60 nm film of poly(3,4-ethylenedioxythiophene)-poly(styrenesulfonate) (Baytron $\mathrm{P} \circledast$ ) and dried at $115{ }^{\circ} \mathrm{C}$ for $15 \mathrm{~min}$. Layers of the donor and $\mathrm{C}_{60}$ were thermally evaporated in a Plassys ME300 chamber at a pressure of about $10^{-6} \mathrm{mbar}$ and at rate of $\sim 1.5 \AA \mathrm{s}^{-1}$. A glass slide placed near the ITO substrates was used to obtain samples for UV-Vis absorption spectra. The devices were completed by the evaporation of aluminium films (ca. $60 \mathrm{~nm}$ thick) as negative electrodes. A shadow mask with openings of $6 \mathrm{~mm}$ diameter was used to define a device's area of $0.28 \mathrm{~cm}^{2}$. After their fabrication, the devices were stored and characterised in a glovebox (200B, MBraun). The J-V curves were recorded in dark and under various light intensities using a Keithley 236 source-measure unit and a home-made acquisition program. Power conversion efficiencies were measured with a Steuernagel Solar constant 575 simulator. Light intensity was measured with a calibrated broadband optical power meter (Melles Griot) and was varied with neutral density filters. The devices were illuminated through the ITO electrode side. The efficiency values were neither corrected for a possible spectral mismatch of the light source with the solar spectrum nor for the absorption/reflection losses at the various interfaces. EQE was measured with a Perkin Elmer 7225 lock-in 
amplifier under monochromatic illumination at variable wavelength at a chopping frequency of $100 \mathrm{~Hz}$. The light source was a tungsten lamp (Acton SpectraPro150).

Absorption spectra were recorded with a Perkin Elmer Lambda 19 UV-Visible-Near IR spectrophotometer. Cyclic voltammetry was performed with platinum electrodes in a threeelectrode cell using an EGG 273 potentiostat.

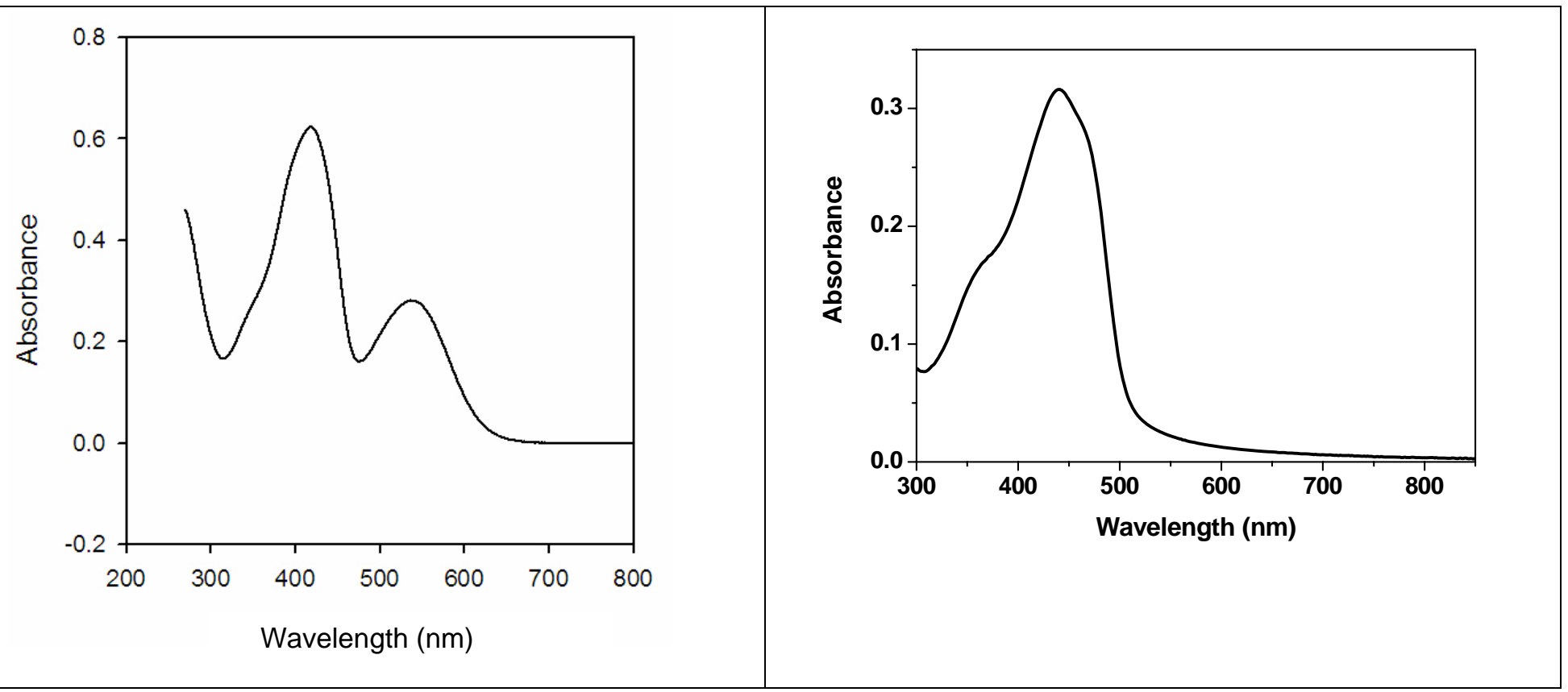




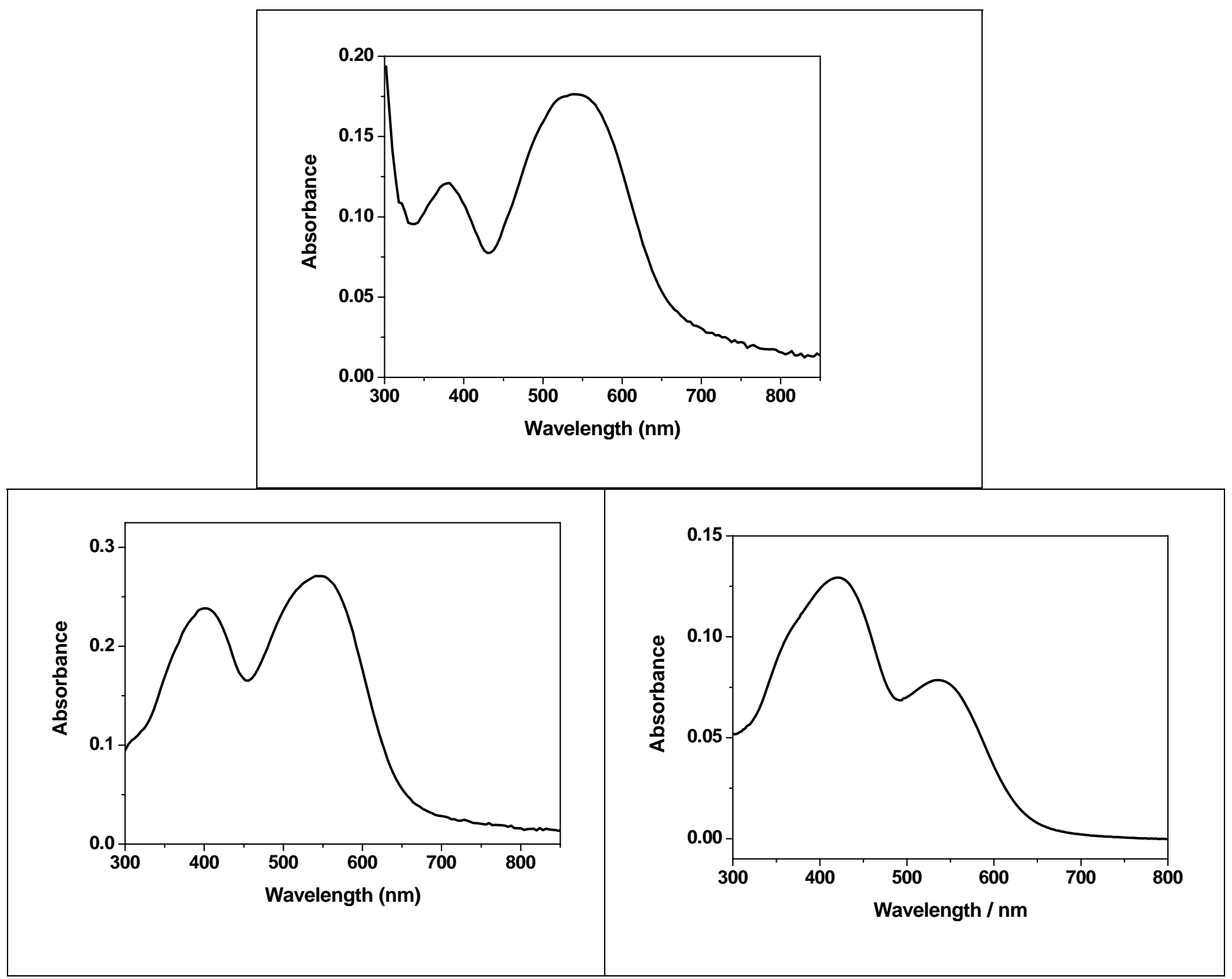

UV-vis spectra of thin films deposited on glass by thermal evaporation under vacuum Top left (2), right (1), bottom left (3), right (4) 
UV-vis spectrum of thin film of $\mathbf{5}$ deposited on glass by thermal evaporation under vacuum 

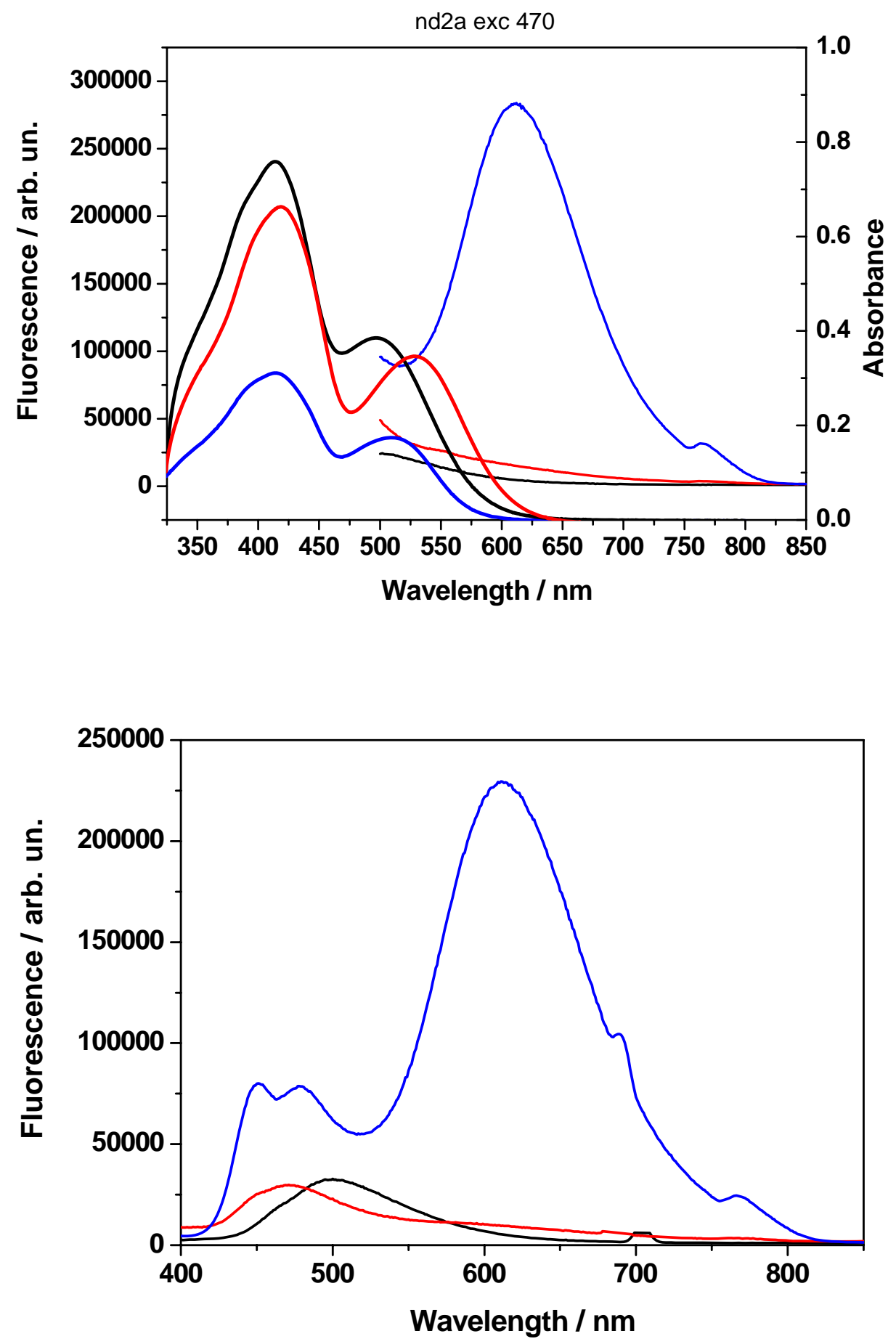

Fluorescence emission spectra of compound 3 (top) and 4 (bottom) blue toluene, black: dichlorobenzene, red: acetone. Excitation wavelength top $470 \mathrm{~nm}$, bottom $370 \mathrm{~nm}$ 


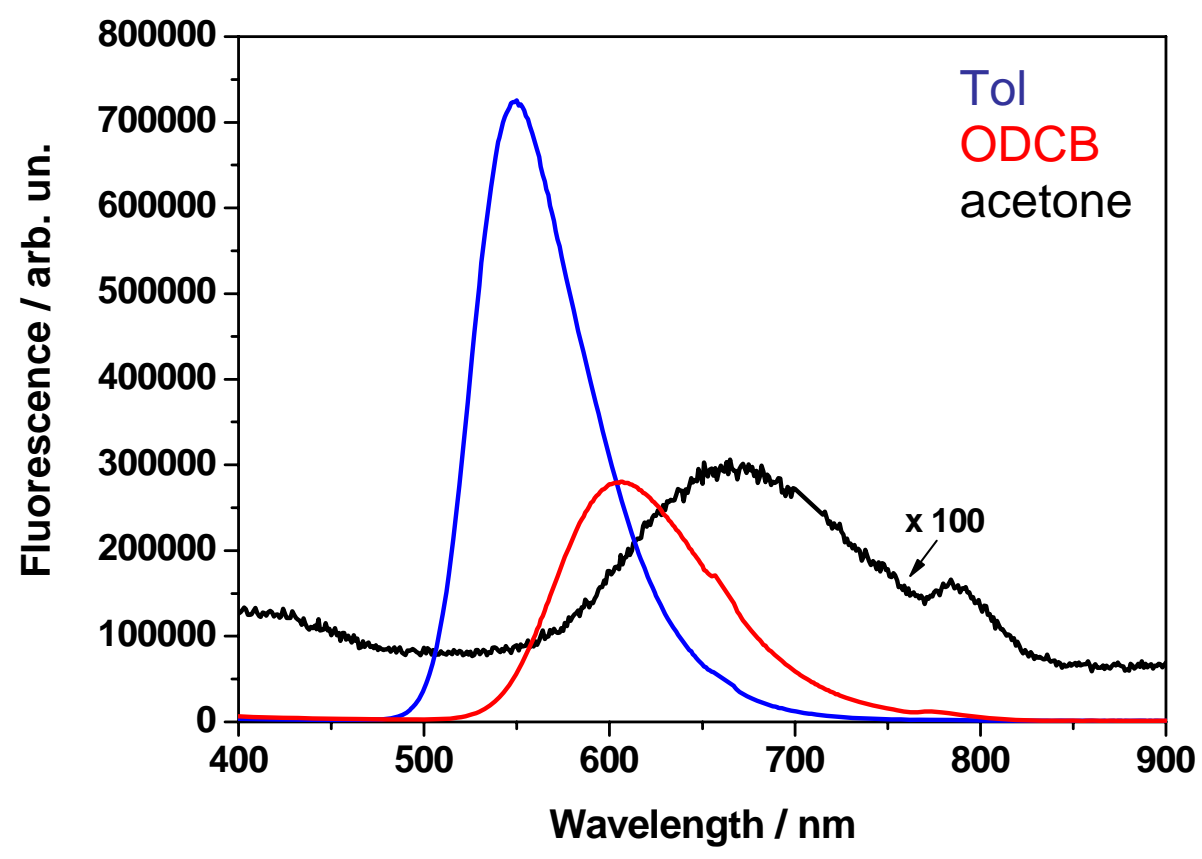

Fluorescence emission spectra of compound 5: blue toluene, black: dichlorobenzene, red: acetone. Excitation wavelength $370 \mathrm{~nm}$. 


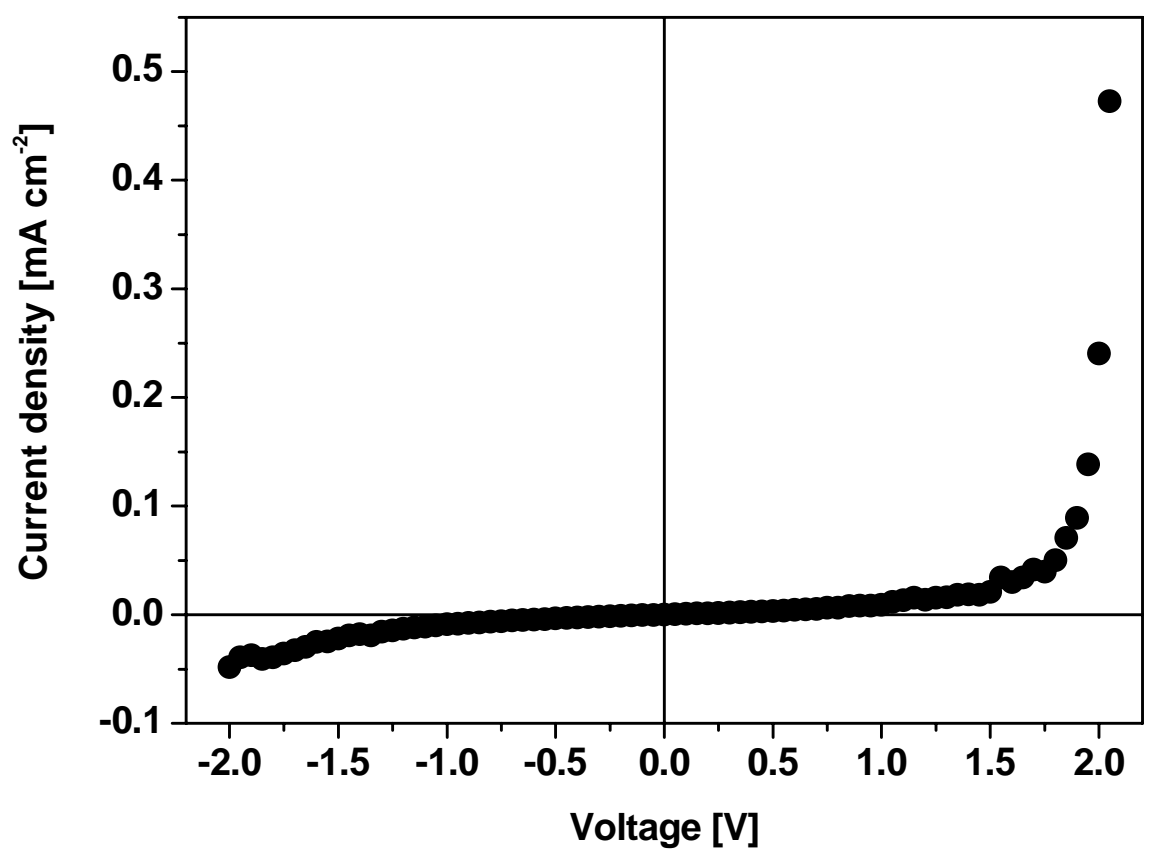

Current voltage curve of the cell ITO/1 $(25 \mathrm{~nm}) / \mathrm{C}_{60}(25 \mathrm{~nm}) / \mathrm{Al}(60 \mathrm{~nm})$ 